\title{
A DIALOGUE ON THE SPORTS TRAINING THEORIES IN PROFESSIONAL AND SCIENTIFIC PERIODICALS
}

\author{
Adam Petrović \\ Sports Academy Belgrade, Serbia
}

\begin{abstract}
The purpose of a scientific dialogue is to overcome existing problems, participate responsibly, and find out the real nature of an issue, rather than to "be enclosed within a room” with one theory - studying one theory until its ultimate purpose is revealed. The dialogue preceded by a problem presented in a sincere and „risky” way and followed by a responsible attempt to solve the presented problem can be considered the true scientific dialogue. Establishing the criteria for conducting a dialogue may be relevant for discovering the reality in a scientific discipline. The dialogue on the sports training theories has been ongoing and the main aim of this paper was to overcome the problems related to the ",rival theories" - the traditional theory of sports training versus the theory of the sports training block periodization. A weakness of the current dialogue on the sports training theories is a small number of the criteria on which the discussion on the „rival theories" is based. The dialogue should be conducted repeatedly in order to find a more tolerant attitude towards the other/different or in order to strengthen the already existing opinion.
\end{abstract}

Key words: SPORTS TRAINING THEORY / DIALOGUE / TRADITIONAL THEORY / BLOCK PERIODIZATION / SCIENTIFIC JOURNALS

\section{INTRODUCTION}

\section{The importance of a scientific dialogue}

The basic motive for conducting a scientific dialogue can be knowledge expansion, scientific advancement, the maturing of science and dialogue participants as well as overcoming the problems that have been observed so far. The dialogue can define the value and significance of a particular problem, which indicates that not all of the scientific problems are significant and not all of the dialogues are relevant either. It is not easy to participate in a scientific dialogue, but it is worth to be tormented by this "exalted torment”. This has been confirmed by the so-far history of conducting dialogues, not only on the sports training theories, but also on the theories in other scientific disciplines.

The purpose of a scientific dialogue is to overcome existing problems, participate responsibly, and find out the real nature of an issue, rather than to „be enclosed within a room” with one theory - studying one theory until its ultimate purpose is revealed. Any dialogue can be considered fruitful if the hierarchy of the values of the dialogue subject matter is not violated, and if the answers to relevant questions are searched for in a variety of different ways. In a dialogue, the "little things” should not replace the „big ones.” A dialogue participant should have such a determination and be ready to defend his attitudes, but also to correct them if the requirements for doing so are met. This suggests that the purpose of a dialogue is not „a mental spectacle”, but a sincere intention to improve oneself through knowledge, the maturing of science (although science never matures completely!), the designing of science or a scientific discipline.

The dialogue preceded by a problem presented in a sincere and "risky" way and followed by a responsible attempt to solve the presented problem can be considered the true scientific dialogue. It is hard to imagine that something can be found out without internal struggle, without the dialogue which includes opposing opinions as well as without the di- 
alogue which contains the opposite within itself. No scientific dialogue is truly set up if it is not done in a „risky” manner, i.e. if it does not include the creativity in its interpretation or the uncertainty in its findings. The dialogue may result in new knowledge, i.e. new interpretation of the existing postulates within scientific theories. The results of a scientific dialogue can be a larger amount of knowledge which may direct the course of the scientific discipline development in further research. Additionally, it should be understood that new research directions are established only after a good dialogue. This suggests that not all of new scientific findings are significant, therefore not all of the previous knowledge should be rejected and vice versa. A good dialogue is distinguished by accepting "new” and "old" findings and a theory is more valuable if it is "more permanent" rather than "more modern”. The permanence, understanding and interpretation of a theory represent the main values and novelties of scientific knowledge.

According to Jerotić (Јеротић, 2013) a dialogue is "A conversation conducted with a man of the opposing opinion in relation to ours (it does not matter if this opposing opinion is of religious, philosophical, scientific or political nature); the conversation should be repeated several times and, importantly, it should be devoid of the presence of affections. The result of the dialogue conducted in this manner is also known: the enrichment of the personalities of both conversation participants, either in terms of a partial or a complete change of the previous opinion (our thought often becomes our faith, either positive or negative, tolerant or intolerant) or in respect of the fruitful strengthening and consolidation of the previous opinion ".

\section{THE BASICS OF THE DIALOGUE ON THE SPORTS TRAINING THEORIES - TRADITIONAL THEORY VS BLOCK PERIODIZATION}

Two "rival" sports training meta-theories will be presented herein as well as a brief introduction to the overall discussion and dialogue and the issues of the sports training theory. In the literature, the first theory is recognized and known as "the traditional theory of sports training (TTST)", but other terms, such as "anecdotal" or "Matveyev's theory", are also used in regard to it. On the other hand, there is a new approach, i.e. the theory that has been accepted and titled the "theory of the sports training block periodization (TSTBP)" or shorter the "block system" or "block periodization" of sports training.

The supporters of the theory of the sports training block periodization have confronted the traditional theory of sports training enthusiastically. However, we should bear in mind that in the overall theoretical discussion there are some authors who wrote about the issues of the sports training theory but without entering into the said dialogue. On the basis of their works it may be observed to which side their theory with all its particularities belongs, i.e. on which theoretical assumptions their scientific thought has be based upon. This suggests the understanding of two "research programmes" as the foundations of scientific knowledge in the field of sports training science as well as many other (not less important!) sports training theories which have a sort of unifying character.

Matveyev (Матвеев, 1964) first presented the theory of sports training as an organized scientific and logical whole, which was later recognized as the "traditional theory of sports training" in the literature. The aforementioned theory represented a need to regulate a large amount of practical knowledge that existed during that period. In 1950s, it was possible to predict how the sports training theory would develop and to define its problems (Озолин, 1951, 1959). In his later studies, Matveyev (Матвеев, 1977) attempted to complete his previous work based on the theory of sports training. In a simplified sense, all the works were aimed at answering the question of how the best sports results should be achieved in the important competitions, such as the Olympic Games, World Cup or European Championship. Later, Matveyev (Матвеев, 1998b) gradually switched from the theory of sports training to the general theory of sports. In his latest studies, Matveyev (Матвеев, 2010) supplemented and formulated his own general theory of sports, which was published as a book in several editions. By attempting to solve the problem of the general theory of sports, the sports training theory has practically started to gain its significance.

From the aspect of the development of the science of sports and sports training, a paradoxical fact has emerged. Namely, as Matveyev was designing his general theory of sports, as well as the theory of 
sports training therein, the criticism of such considerations was strengthened, particularly by Verkhoshansky - one of the greatest critics of the traditional theory of sports training. The criticism has been expanded by Issurin and Shklyr (Issurin, 2010; Иссурин, 2010; Иссурин \& Шкляр, 2002) who have supported the theory of sports training block periodization and elaborated the initiated idea of the sports training block system.

On the other hand, Platonov (Платонов, 1998), Kiely (Kiely, 2010) and Koprivica (Koprivica, 2012) have opposed the sports training block system pointing out numerous problems and failures that the supporters of the block system failed to present. Generally speaking, in physical culture, there is practically none or a small number of areas where a dialogue has been started on a theoretical level between the authors of different opinions. However, in the field of the sports training theory, the dialogue has been conducted and but also avoided between the authorities who have made a major contribution to the development of the above mentioned science. In this sense, if the science is observed from the viewpoint of the "criticism" by Popper (1973), it may be easily noticed that in physical culture the discussion about the sports training theory is a rather developed part of the science. Although physical culture "craves" theoretical discussions and criticism in any of its fields of study, the great theoretical discussions have been started and are ongoing in the field of the sports training theory. In this respect, all the participants in the dialogue - now on a global scale - should be acknowledged. Such dialogues, in fact, lead to scientific independence as well as to the formation of scientific disciplines and the transition to a higher level of understanding and interpretation of a certain scientific discipline.

The aforementioned critic Verkhoshansky (Верхошанский, 1998a, 1998b) boldly started a dialogue in the field of the sports training theory. In his articles, Verkhoshansky has launched a very severe criticism of Matveyev's theory. Verkhoshansky (Верхошанский, 2005) has elaborated the original hypothesis of the new sports training theory, which has been given its full name of the sports training block system.

What has Verkhoshansky actually criticized Matveyev for? The criticism has started with stating that the traditional approach "lost its battle" with time since it has not been based on the recent biologi- cal findings which, according to the critics, play a key role in understanding the process of controlling sports form. This fact has been confirmed by many experts around the world in the field of sports training. Furthermore, Verkhoshansky has not denied the importance of the philosophy of science, methodology or pedagogy, but he has given priority to the objective knowledge that is acquired through experiments and practice. This primarily implies the findings in the field of philosophy, biochemistry or biomechanics. On the basis of these findings, he has developed his own theoretical system with its terminology and regulation methods. Verkhoshansky has criticized the traditional approach to the sports training theory on several occasions, but it seems that he presented it in the most comprehensive manner in his work "On the way of the scientific theory and methodology of sports training" (rus. На пути к научной теории и методологии спортивной тренировки containing seven items, where he stated the following) (Верхошанский, 1998b):

- the cardinal error of the CSTP (the concept of sports training periodization) which deprives it of both theoretical and practical relevance is the disregard of biological findings and scientific achievements in the field of sports;

- the consequence of the methodological and scientific inadequateness of the CSTP is an obvious conceptual mess of "laws”, "principles”, „basic starting points”, "principle starting point”, „ characteristics / features of laws", and this mess has been caused by a strange and hopeless attempt to find regularities in the experience of sports training development;

- the speculative and logical basis of the CSTP was derived from the so-called phases of the sports form;

- "the general pedagogical approach" has not been based on: a serious natural scientific basis, objective and quantitative criteria of its subject matter or a strict scientific method, therefore there is no theoretical and methodological basis of the sports training theory;

- serious criticism by the experts-practitioners is related to the very essence of the CSTP - a formal and mechanical classification of the training process into subjectively formed parts (cycles, phases, periods), which represented the main idea as well as the purpose of the CSTP; 
- the technology of the training process development is a part of the CSTP which is least developed and based on the principle „it can be done either way";

- one of the most important shortcomings of the CSTP is that it allows only two regulation methods / ways (volume and load intensity) of the impacts of training on an athlete.

The criticism started by Verkhoshansky was expanded by Issurin (Иссурин, 2010, p. 101-106), who stated the following TTST contradictions:

- traditional planning is suitable for the athletes of low and middle qualifications. However, it does not function well with top-level athletes;

- parallel application of different loads contributes to the adequate provision of energy,

- due to the heterochrony of physiological systems' recovery, athletes are not recovered adequately;

- the exercises used in the application of different training methods often have adverse reciprocal effects due to energy deficits, technical complexity and/or nervous and muscle fatigue;

- the application of high loads during a training session requires a high degree of psychological concentration which cannot be directed towards multiple objectives at the same time;

- the specific progression of top-level athletes requires the application of large-scale training effects which cannot be organized during a training session due to a large number of objectives.

On the other hand, Matveyev (Матвеев, 1998a) has reminded Verkhoshansky of his neglect of the recent research on the sports training theory and a comprehensive approach to the study of sports training as well. In fact, these recent studies have been practically tested and confirmed by many scientific and sports professionals worldwide. Matveyev has reminded that therefore it remained unclear why Verkhoshansky did not appreciate the opinions of other authors and experts who made a great contribution to the dynamics of the traditional sports training theory development. However, according to Matveyev, it seems that the key problem in the overall discussion is the understanding of the unity of competition dynamics and training process and athletes as its participants. Matveyev is a supporter of a holistic approach including creative processes and outcomes, and he considers it inadmissible to partially examine only one of numerous issues of the now general theory of sports. This attitude may be best observed in his statement: „To initiate a severe standardization means to enter into irreconcilable contradictions of the live training process variation."

In addition to Matveyev, other authors also remarked on the block system of the sports training, among which Platonov (Платонов, 1998) can be singled out by expressing his disagreement with Verkhoshansky's theory in the following way:

- the criticism has been reduced to the analysis of only one of the numerous components of the sports training system - the concept of periodization published by Matveyev in 1964 and 1977. Thus, the crisis of not only domestic but also the Eastern European sports training theory has been introduced;

- Verkhoshansky criticized Matveyev for disregarding biological findings and Matveyev's thesis where sport pedagogical and biological knowledge interweave has been widely known. This is confirmed in the literature referred to by Matveyev - more than a half of the references belong to the fields of physiology, biochemistry and sports medicine;

- bibliographical indicators about the most important articles have been excluded;

- criticizing Matveyev, Verkhoshansky has referred to the fact that Matveyev's theory cannot be understood in the West. This statement has been questioned since the experience gained in the dialogue with the experts from Japan, China, America and Canada has confirmed the opposite - the theory of sports preparation periodization as well as different variants of its practical implementation were developed by the experts of the USSR and the GDR during 1970 s and 1980s, representing one of the few fields of study where experts from all around the world have given unconditional priority to the Eastern European scientific school. Like it or not, they have been treating this contribution with respect and it is known that Matveyev has contributed most to the development of the aforementioned Eastern European school;

- Platonov believes that Verkhoshansky's theory does not differ substantially from Matveyev's theory regarding the principles, stating 
that the difference can only be noticed in that Verkhoshansky has introduced some new terms, previously unknown to both the experts from the Russian speaking countries (rus. отечественных) as well as to the foreign ones - this has resulted in nothing but confusion;

- the issues discussed cannot be reduced to only one problem consistently emphasized by Verkhoshansky;

- at this point, it should be added here that Platonov has also fiercely confronted the views expressed in Verkhoshansky 's work titled "Horizons of the studied theory and methodology of sports training" (Russian: Горизонты научной теории и методологии спортивной тренировки).

Platonov (Платонов, 2008, p. 17-20) has severely opposed Verkhoshansky's theory in his recent works as well:

- many elements of the criticism are „absurd”, ambitious and based on a tendentious and sometimes rough presentation of the basic postulates of the periodization theory. All of this is aimed at creating an own, alternative theory of the training process programming and organization;

- Verkhoshansky has expressed his emotional criticism, but not the scientific and practical one;

- if this issue is approached objectively, it is very difficult to notice what new concepts have been introduced by Verkhoshansky to the knowledge system, relating to the development of the elite athletes' preparatory process throughout a year and macrocycles. His claim to the discovery of a unique and previously unknown phenomenon is vague and unclear;

- the proposed principle, regarding goal-oriented loads (the loads that develop only one ability) and including a great intensity-recovery-delayed adaptation effect had been thoroughly considered by many authors, such as Consilman, Ozoline, Harre, Matveyev and others, much before Verkhoshansky wrote about it;
- unidirectional concentration of loads with a high volume of work, which is characteristic of modern sports, also includes other risks: 1) a possibility of functional uptake (pre-adaptation), 2) a reduction in structural and functional reserves of other systems (de-adaptation), which are not engaged to the extent necessary when performing the work.

Kiely (Kiely, 2010, p. 803) has also joined the existing criticism of the theory of block periodization, reminding that Issurin prematurely and unsustainably talked about the "new horizons" of the training periodization. There are two main reasons for this: a) anecdotal - it includes the selected cases/examples of the athletes and coaches who have achieved high levels of success using a block-training design; 2) "two modern scientific concepts" related to the cumulative and residual effect of training, in fact, do not represent anything new. Indeed, Matveyev is the most famous author of the traditional periodization model and he has also taken into account the cumulative effect of training and the concepts that correspond with the residual training effect in his influential work "The Basics of Sports Training". Eventually, Kiely (Kiely, 2010, p. 804) has concluded that a more appropriate description of the block periodization should be a "new variant" rather than a "new horizon" in the sports training planning.

The criticism put forth by Kiely was followed by Issurin's reply. Given that Issurin's criticism of the traditional theory of sports training has been already presented in this paper, his response to Kiely will be omitted.

Recently, the discussion has been taking place in a way of outvoting character which is, it may be said, insufficiently justified in scientific terms. Namely, in the study of García-Pallarés et al. (García-Pallarés, García-Fernández, Sánchez-Medina, and Izquierdo, 2010) the effects of two training models (traditional periodization and block periodization) on the change in competitive abilities in top-level kayakers have been compared. "The design of the study" is shown in the Figure 1 and it briefly summarizes the training plan, the main training objectives and the testing calendar for both cycles. 




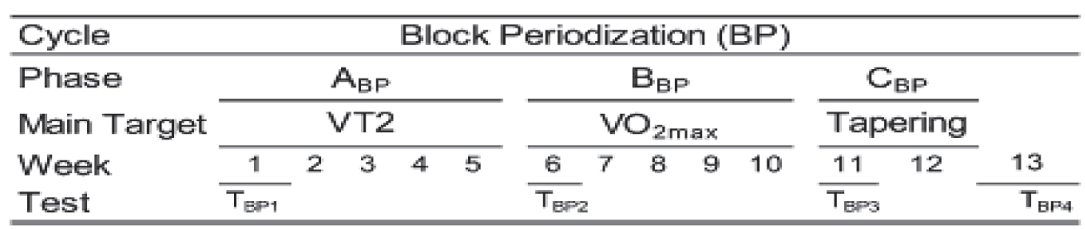

Figure 1. Design of the study; Summary of the training plan, main training objectives and testing calendar for both cycles. Adapted from García-Pallarés et al. (2010).

Based on such a "design of the study", it may be concluded that the block periodization is a better means of planning compared to the traditional periodization and it greatly improves the skills that are important for kayakers (García-Pallarés et al., 2010). However, if the proposed "design of the study" is closely observed, it may be also concluded that these authors have differentiated the block periodization and the traditional periodization only by the volume of the loads, disregarding that the model of a volume and intensity ratio is analogous - almost the same in TTST and TSTBP. Additionally, the criticism of the traditional periodization has been expressed without any reference to the traditional periodization of sports training included in the references. Such a dialogue is not simply methodologically justified because it does not show the maturity required for the highest level of discussion about the theory of sports training. García-Pallarés et al. (2010) have not considered the classical concepts of the traditional and block periodization in detail, but interpreted them freely in a speculative way.

A similar principle has been presented in other studies (Carazo-Vargas, González-Ravé, Newton, and Moncada-Jiménez, 2015; Rønnestad, Ellefsen, et al, 2014; Rønnestad, Hansen, and Ellefsen, 2014), which have also criticized the traditional model of sports training periodization out of context and in a completely loose and, in some cases, even chimeric way. The aforementioned authors have entered into the criticism of the partial elements of the traditional theory reducing it to what it is not, without referring to a single quote of the authors who have designed the traditional model.
The research problem discussed and presented above is primarily of a scientific significance, the purpose of which has emerged in the dialogue. However, it is not about any kind of dialogue, but the dialogue that will have clear postulates as well as its beginning and its ending. The scientific dialogue with its beginning and ending should also deal with a wider sense of human existence and understanding. Although this is not usually associated with the scientific necessity, suggesting that it is also possible to conduct research in other ways, without taking into account a broader context of understanding certain issues - the holistic understanding versus the particularistic one. In addition, the understanding of man through science should be developed in two directions: in breadth and in depth. Otherwise, the man whom the science has been trying to define and understand could be easily simplified without such a consideration. Therefore, it is necessary to examine the way in which the problem of the overall theory of sports training has been presented as well as how the conclusions regarding the theory of sports training have been drawn. In other words, can the purpose and aim of the sports training theory be beyond the purpose of man?

It should be added here that the dialogue conducted within the sports training theory is of a "purely scientific character" which includes a shortcoming. Namely, if we consider how these two theories / concepts are constituted, and how the dialogue has been conducted, then it can be easily noticed that the dialogue is based on factual knowledge. However, such factual knowledge in the sports training theory imposes an important question: according to which norms / criteria are the facts attributed to one theory more valuable in content than the facts attributed 
to another theory? The authors have often referred to their own studies, but also to the ones which have factually proven the basic postulates of one theory or the other. The dialogue based on such tendencies seemed justified in the previous discussions; however, after a lot of criticism expressed repeatedly by both sides, the circumstances that have occurred within this scientific community have started to resemble "outvoting" rather than a valid scientific dialogue within the sports training theory. Simply, the leading scholars have not reached the consensus on the most important issues of the sports training theory yet.

A possible solution to the problems relating to the sports practice, i.e. the practical problems of "lower class" but of equal importance, arises out of the aforementioned. In fact, these are the problems of selecting and approaching one of the proposed systems and its application in practice.

\section{THE CRITERIA FOR CONDUCTING A DIALOGUE ON THE THEORIES OF SPORTS TRAINING}

A scientific dialogue in the function of assessing and comparing theories opens up a whole series of problems related to the logic and philosophy of science, methodology, and the phenomenon examined in a scientific field as well as to solving practical and other problems. Since science is based on criteria, it is reasonable to ask according to which criteria the scientific theories that deal with solving problems of the same reality in a field of study are assessed and compared and what the term criterion actually means.

Criterion, criteria (Greek: kritērion, according to krínein) means: 1. the basis on which something is assessed, classified or differentiated from something else, a standard. 2. sp. elimination competition (Клајн \& Шипка, 2008, p. 681).

Recently, the three sets of criteria for assessing and comparing the theories of sports training have been identified $^{1}$ :

1) nature and origin of knowledge in the sports training theories - the criteria based on epistemological beliefs;

\footnotetext{
1 More details about the criteria are included in the doctoral dissertation : Petrovic, A. Sports training theories: possibilities of evaluating and comparing. Doctoral dissertation defense under preparation.
}

2) research method used in elite sports, where special attention is paid to understanding the application of scientific methodology in sports training sciences - the criteria based on methodological beliefs and

3) comparison of scientific theories, i.e. providing the justification of a theory within the system of a scientific discipline - the criteria based on a multidisciplinary approach of assessing and comparing scientific theories, which include, e.g. logic, probability, boldness and / or simplicity of a theory.

It should be pointed out that the previous discussion within the theory of sports training was mostly based on the criteria of narrow professional orientation. These criteria and their knowledge outcomes are largely characterized by practical knowledge. Namely, the justification of a sports training theory by different authors was directed mainly towards the understanding of the training practice as one of the major criteria of theoretical justification. Certainly, the practical outcomes of a theory, regarded as a phenomenon, are significant for sports and sports training. However, is it justifiable to assess a theory only on the basis of the practical outcomes? By all odds, no! Why? Such an approach of declaring "for" and "against” a theory on the basis of only one criterion (in this case the practice is considered the outcome) can greatly refer to a particularistic understanding of the problem. Practice is just one segment, part, grain of the understanding of an issue that strives to become or is scientific.

In this paper, the thesis that the dialogue within the theory of sports training should be extended from predominantly practical criteria to predominantly scientific ones according to which the theories (hypotheses) of sports training can be assessed and compared has been advocated for. This does not mean that practice is not a scientific criterion, but it does not mean either that practice is the only scientific criterion when it comes to the theory of sports training.

\section{CONCLUSION}

The expansion of scientific knowledge is a long and painstaking work. A dialogue is one of the basic ways / methods of the science improvement. When selecting a problem, the problems that are relevant for the dialogue and those that are not should be differentiated. The relevant problems are characterized by boldness to expand the knowledge by presenting the problems in a "more risky” way. To present a problem 
which does not include uncertainty actually means to hinder the knowledge, improvement, progress, and hence the scientific discipline.

In the theory of sports training, the dialogue between the supporters of two meta-theories: the traditional theory of sports training and the theory of the sports training block periodization has been ongoing. The basic motive of the ongoing dialogue is to deny or to reject the traditional theory of sports training. The mentioned dialogue should not be interrupted, but it should be conducted repeatedly, taking into account the "new” and "old" findings, and not only in order to reject one of the theories, but to acquire more objective knowledge. Sometimes, something that the theories have in common may be more valuable than that what separates them. The dialogue means a new opportunity given to the supporters of both sports training concepts for the future elaboration of the scientific thought on sports training.

As for a fruitful dialogue, we should add the criteria according to which it is conducted, i.e. on the basis of which the sports training theories are assessed and compared. A small number of the criteria that have been insisted on by the supporters of TSTBP has been undermining the dialogue. In the theory of sports training, the training practice has been imposed as the basic criterion. Of course, practice is one of the important criteria, but other criteria should not be discarded, such as those relating to epistemological and methodological beliefs, as well as the logic, boldness, probability, simplicity of the theory, etc. - a multidisciplinary approach to assessing and comparing the sports training theories. In this sense, we should thank Verkhoshansky and his followers

\section{REFERENCES}

1. Carazo-Vargas, P., González-Ravé, J. M., Newton, R. U., и Moncada-Jiménez, J. (2015). Periodization Model for Costa Rican Taekwondo Athletes. Strength \& Conditioning Journal, 37(3), 74-83.

2. García-Pallarés, J., García-Fernández, M., SánchezMedina, L., и Izquierdo, M. (2010). Performance changes in world-class kayakers following two different training periodization models. European journal of applied physiology, 110(1), 99-107. for entering into the dialogue with the supporters of the traditional theory of sports training boldly and "risky", thus improving the scientific knowledge about sports training, but we should regret that their "scope of knowledge" has been reduced only to the "hard core”, i.e. empirical knowledge. Thus priority has been given to the particularistic understanding of the basic postulates of the sports training theory, disregarding the holistic understanding which has been reminded of by the TTST supporters.

Continuous enrichment through the dialogue will result in tolerance towards the different and the other, however, this does not mean that science should be relativized through the attitude suggesting that "everything is allowed," but it implies an attempt to improve individuals, scientific community and knowledge within a certain science more objectively. The doubt should not be cast on the fact that a dialogue is a reliable way / manner / method of the maturing and expanding scientific knowledge.

In 1999, soon after the severe discussion between the supporters of TTST and TSTBP, Jevtic suggested the basic problems that arise in the theory of sports training on the pages of the Physical Culture journal, which represents an attempt to enhance the spirit of a scientific dialogue in the Serbian periodicals as well.

\section{NOTE}

The excerpts and supplements taken from the unpublished doctoral dissertation (defense under preparation): Petrović, A. Sports training theories: possibilities of evaluating and comparing. Doctoral Dissertation, Serbia, Faculty of Sport and Physical Education.
3. Issurin, V. (2010). New horizons for the methodology and physiology of training periodization. Sports medicine, 40(3), 189-206.

4. Kiely, J. (2010). New Horizons for the Methodology and Physiology of Training Periodization: Block Periodization: New

5. Horizon or a False Dawn?; The Author's Reply by Issurin, V. Sports medicine, 40(9), 803-808. 
6. Koprivica, V. (2012). Block periodization-a breakthrough or a misconception. Sport Logica, 8(2), 93-99.

7. Poper, K. R. (1973). Logika naučnog otkrića (S. Novaković, превео). Beograd: Nolit.

8. Rønnestad, B. R., Ellefsen, S., Nygaard, H., Zacharoff, E. E., Vikmoen, O., Hansen, J., u cap. (2014). Effects of 12 weeks of block periodization on performance and performance indices in well-trained cyclists. Scandinavian journal of medicine \& science in sports, 24(2), 327-335.

9. Rønnestad, B. R., Hansen, J., и Ellefsen, S. (2014). Block periodization of high-intensity aerobic intervals provides superior training effects in trained cyclists. Scandinavian journal of medicine \& science in sports, 24(1), 34-42.

10. Верхошанский, Ю. (1998а). Горизонты научной теории и методологии спортивной тренировки. Теория и практика физической культуpbl(7), 41-54. Retrieved from http://lib.sportedu. ru/Press/TPFK/1998N7/p41-54.htm

11. Верхошанский, Ю. (1998b). На пути к научной теории и методологии спортивной тренировки. Теория и практика физической культуpal(2), 21-41. Retrieved from http://lib.sportedu. ru/Press/TPFK/1998N2/p21-26,39-42.htm

12. Верхошанский, Ю. (2005). Теория и методология спортивной подготовки: блоковая система тренировки спортсменов высокого класса. Теория и практика физической культурьы(4), 2-14. Retrieved from http://lib.sportedu.ru/Press/ TPFK/2005N4/p2-14.htm

13. Иссурин, В. (2010). Блоковая периодизаиия спортивной тренировки: монография. Москва: Советский спорт.

14. Иссурин, В., и Шкляр, В. (2002). Концепция блоковой композиции в подготовке спортсме- нов высокого класса. Теория и практика физической культуры (5), 2-5.

15. Јеротић, В. (2013). Нема сазревања без ступања у дијалог са људима супротног мишљења. Куличира, 140, 18-23.

16. Клајн, И., и Шипка, М. (2008). Велики речник ситраних речи и израза. Нови Сад: Прометеј.

17. Матвеев, Л. (1964). Проблема периодизации спортивной тренировки. Москва: Физкультура и спорт.

18. Матвеев, Л. (1977). Основы спортивной тренировки. Москва: Физкультура и спорт.

19. Матвеев, Л. (1998a). К дискуссии о теории спортивной тренировки. Теория и практика физической культуры (7), 55-61.

20. Матвеев, Л. (1998b). От теории спортивной тренировки-к общей теории спорта. Теория $и$ практика физической культуры (5), 5-8.

21. Матвеев, Л. (2010). Общзая тория спорта и ее прикладные аспекты. Москва: Советский спорт.

22. Озолин, Н. Г. (1951). О планировании спортивной тренировки. Теория и практика физической культуры(11), 848-855.

23. Озолин, Н. Г. (1959). Советская система спортивной тренировки. Теория и практика физической культуры(1), 7-11.

24. Платонов, В. (1998). О «Концепции периодизации спортивной тренировки» и развитии общей теории подготовки спортсменов. Теория и практика физической культуры (8), 23-26.

25. Платонов, В. (2008). Теория периодизации подготовки спортсменов высокой квалификации в течение года: предпосылки, формирование, критика. Наука в олимпийском спорте(1), 3-23. 


\title{
DIALOG ÜBER THEORIEN DES SPORTTRAININGS IN FACHLICHER UND WISSENSCHAFTLICHER PERIODIK
}

\begin{abstract}
Zusammenfassung:
Der Zweck eines wissenschaftlichen Dialogs ist die Überwindung existierender Probleme, verantwortungsvolle Teilnahme, Kenntnis der Realität einer natürlichen Wirklichkeit im Gegenteil zu dem „Sich einschließen im Zimmer“ mit einer Theorie, der Erforschung einer Theorie, bis wir ihrem endgültigen Sinn auf den Grund kommen. Als eigentlicher wissenschaftlicher Dialog kann ein Dialog angesehen werden, dem ein ehrlich und "gefährlich“ gestelltes Problem vorangeht. Danach folgt ein verantwortungsvoller Versuch, das gestellte Problem zu lösen. Die Stellung der Kriterien, nach denen ein Dialog geführt wird, kann für die Kenntnis der Realität in einer wissenschaftlichen Disziplin wertvoll sein. Der Dialog über Theorien des Sporttrainings wurde vor langer Zeit begonnen; das Grundziel dieser Arbeit ist die Überwindung der Probleme, die sich auf „Theorien der Gegnerinnen“ beziehen - traditionelle Theorien des Sporttrainings gegenüber der Theorie der Blockperiodisierung von Sporttrainings. Das Problem des bisherigen Dialogs über Theorien für Sporttrainings war eine geringe Anzahl an Kriterien, auf Grund denen über „Theorien der Gegnerinnen“ diskutiert wurde. Der Dialog sollte widerholt werden, um zu einer toleranteren Einstellung gegenüber Anderem/Andersartigem zu gelangen oder um eine Meinung zu verstärken, die schon exixtierte.

Schlüsselwörter: THEORIE DES SPORTTRAININGS / DIALOG / TRADITIONELLE THEORIE / BLOCKPERIODISIERUNG / WISSENSCHAFTLICHE ZEITSCHRIFTEN
\end{abstract}

Received: 04. 11.2017.

Accepted: 05. 12. 2017. 


\title{
ДИЈАЛОГ О ТЕОРИЈАМА СПОРТСКОГ ТРЕНИНГА У СТРУЧНОЈ И НАУЧНОЈ ПЕРИОДИЦИ
}

\author{
Адам Петровић \\ Спортска академија Београд, Србија
}

\begin{abstract}
Сажетак
Сврха научног дијалога је превазилажење постојећих проблема, одговорно учествовање, упознавање реалности неке природе стварности, а не „затварање у собу“ са једном теоријом - проучавање једне теорије док се не сазна шта је њен крајњи смисао. Правим научним дијалогом може се сматрати дијалог коме претходи искрено и „опасно“ постављен проблем након чега следи одговоран покушај решавања постављеног проблема. Успостављање критеријума по којима се води дијалог може бити од вредности за упознавање реалности у некој научној дисциплини. Дијалог о теоријама спортског тренинга одавно је започет, а основни циљ овог рада је превазилажење проблема који се односе на "теорије супарнице“ - традиционалне теорије спортског тренинга спрам теорије блок периодизације спортског тренинга. Проблем досадашњег дијалога о теоријама спортског тренинга је мали број критеријума по којима се расправља о „теоријама супарница“. Дијалог треба изнова понављати како би дошли до толерантнијег става према другоме/другачијем, или, пак, како би учврстили мишљење које је већ постојало.
\end{abstract}

КљУчНе речИ: ТЕОРИЈА СПОРТСКОГ ТРЕНИНГА / ДИЈАЛОГ / ТРАДИЦИОНАЛНА ТЕОРИЈА / БЛОК ПЕРИОДИЗАЦИЈА / НАУЧНИ ЧАСОПИСИ

\section{УВОД}

\section{Важност научног дијалога}

Основни мотив вођења дијалога у науци може бити усавршавање знања, осмишљавање науке, сазревање науке и учесника дијалога, као и превазилажење дотада запажених проблема. Дијалогом се може дефинисати вредност и значај одређеног проблема, што упућује да нису сви научни проблеми од значаја, као и то да нису сви дијалози вредни. Учествовати у научном дијалогу није лако, али је достојно мучити се том „узвишеном муком“. То нам сведочи досадашња историја вођења дијалога, не само о теоријама спортског тренинга, већ и о теоријама у другим научним дисциплинама.

Сврха научног дијалога је превазилажење постојећих проблема, одговорно учествовање, упознавање реалности неке природе стварности, а не „затварање у собу“ са једном теоријом - проучавање једне теорије док се не сазна шта је њен крајњи смисао. Сваки дијалог може се сматрати плодним ако се не наруши хијерархија вредности предмета дијалога, као и ако се о вредним питањима тражи одговор на више различитих начина. У дијалогу „ситнице“ не треба да замене „крупнице“. Учесник дијалога треба да поседује такво осећање којим је спреман да брани своје ставове, али и да их коригује у случају да се стекну услови за тако нешто. То упућује да сврха дијалога није „ментални спектакл“, већ искрена намера да се усавршава човек кроз сазнање, сазревање науке (иако наука никада не сазрева до краја!), осмишљавање науке или неке научне дисциплине.

Правим научним дијалогом може се сматрати дијалог коме претходи искрено и „опасно“ постављен проблем након чега следи одговоран покушај решавања постављеног проблема. Тешко је замислити да се нешто може сазнати без унутрашње борбе, без дијалога који укључује супротно мишљење, као и без дијалога са супротним у себи. Ниједан научни дијалог није истински постављен 
ако није постављен „опасно“, односно ако не носи са собом стваралаштво у тумачењу, или неизвесност у сазнању. Дијалогом може да произађе ново знање, ново тумачење постојећих поставки у научним теоријама. Плод научног дијалога може бити већа количина сазнања која у даљим истраживањима може усмерити ток развоја научне дисциплине. Треба разумети да се нови правци истраживања успостављају, између осталог, тек после доброг дијалога. То упућује да нису сва нова знања вредна у науци, као и то да сва стара знања треба одбацити и обрнуто. Добар дијалог се одликује прихватањем „нових“ и „старих“ знања, а теорија је вреднија ако је „сатрајнија“ него ако је „савременија“. Сатрајност теорије, разумевање и тумачење су главне вредности и новине научног знања.

Према Јеротићу (2013) дијалог је „Разговор вођен са човеком супротног мишљења од нашег (није битно да ли је то супротно мишљење религиозне, философске, научне или политичке природе); разговор треба да буде више пута понављан и, важно је, лишен присуства афеката. Резултат овако вођеног дијалога, такође је познат: обогаћивање личности оба учесника у разговору, било у смислу делимично или потпуне промене дотадашњег мишљења (наша мисао често постаје и наша вера, позитивна или негативна, толерантна или нетолерантна), или плодног јачања и учвршћивања дотадашњег мишљења“.

\section{ОСНОВЕ ДИЈАЛОГА О ТЕОРИЈАМА СПОРТСКОГ ТРЕНИНГА - ТРАДИЦИОНАЛНА ТЕОРИЈА СПРАМ БЛОК ПЕРИОДИЗАЦИЈЕ}

На овом месту биће изложене две метатеорије „супарнице” спортског тренинга, као и кратак увод у целокупну расправу и дијалог, као и проблематику теорије спортског тренинга. Прва теорија, у литератури је препозната и позната под називом „традиционална теорија спортског тренинга (ТТСТ)", међутим, користе се и други изрази када се говори о њој, као што су „официјална” или „теорија Матвејева”. С друге стране, нови приступ, односно теорија одомаћила се под изразом „теорија блок периодизације спортског тренинга (ТБПСТ)“ или скраћено “блок систем” или “блок периодизација” спортског тренинга.
Присталице теорије блок периодизације спортског тренинга енергично су се супротставиле традиционалној теорији спортског тренинга. Међутим, треба имати на уму да у свеукупној теоријској расправи постоје аутори који су писали о проблемима теорије спортског тренинга, али који нису улазили у поменути дијалог. На основу њиховог писања могуће је увидети којој страни припада њихова теорија са свим специфичностима, односно на којим теоријским претпоставкама се темељи њихова научна мисао. То упућује на разумевање два „истраживачка програма“, као темеље научног знања у области науке о спортском тренингу, као и више других (не мање важних!) теорија спортског тренинга које имају својеврсни обједињавајући карактер.

Матвејев (Матвеев, 1964) је први представио теорију спортског тренинга као организовану научно-лоіичку иелину, која је касније препозната у литератури под називом „традиционална теорија спортског тренинга“. Поменута теорија је представљала потребу да се уреди велика количина практичног знања која је до тог периода постојала. Током педесетих година двадесетог века могло се наслутити у ком правцу ће ићи теорија спортског тренинга и какви су њени проблеми (Озолин, 1951, 1959). У каснијим студијама, Матвејев (Матвеев, 1977) је покушао да заокружи свој претходни рад на теорији спортског тренинга. Сав рад упрошћено посматрано имао је за циљ да одговори на питање како постићи најбољи спортски резултат на важним такмичењима, као што су олимпијске игре, светско или европско првенство. Касније је Матвејев (Матвеев, 1998b) постепено прелазио са теорије спортског тренинга на општу теорију спорта. У својим последњим студијама, Матвејев (Матвеев, 2010) је допунио и домислио своју општу теорију спорта која је штампана као књига у неколико издања. Покушајем решавања проблема опште теорије спорта, практично је почела да добија на смислу теорија спортског тренинга.

Посматрано са аспекта развоја науке о спорту и спортском тренингу, појављује се једна парадоксална чињеница. Наиме, како је Матвејев све више осмишљавао општу теорију спорта, и у њој теорију спортског тренинга, тако је критика на рачун таквог размишљања била све јача, пре свих од стране Верхошанског - једног од највећих критичара традиционалне теорије спортског тренинга. 
Критику су проширили Исурин и Шкљар (Issurin, 2010; Иссурин, 2010; Иссурин и Шкляр, 2002) који су присталице теорије блок периодизације спортског тренинга и који су дорадили започету идеју о блок систему спортског тренинга.

Са друге стране, Платонов (Платонов, 1998), Кили (Kiely, 2010) и Копривица (Koprivica, 2012) успротивили су се блок систему спортског тренинга указујући на многобројне проблеме и пропусте које су присталице блок система пропустиле да изнесу. Опште посматрано, у физичкој култури практично не постоји или је мали број области у којој је започет дијалог на теоријском нивоу између аутора различитих схватања. Међутим, у области теорије спортског тренинга, дијалог се води и „разводи“ између ауторитета који су дали велики допринос развоју поменуте науке. У том смислу ако ठи науку посматрали из угла „критицизма” Попера (Poper, 1973) лако се може увидети да у физичкој култури расправа о теорији спортског тренинга представља прилично развијен део науке. Иако физичка култура „вапи” за теоријским расправама и критикама у свим њеним областима проучавања, сјајне теоријске расправе започете су и трају у области теорије спортског тренинга. У том погледу, треба одати признање свим учесницима дијалога - сада већ светских размера. Заправо таквим дијалозима се и долази до научног осамостаљивања, до оформљавања научне дисциплине, до преласка на виши ниво разумевања и тумачења одређене научне дисциплине.

Већ поменути критичар Верхошански (Верхошанский, 1998a, 1998b) смело је започео дијалог у области теорије спортског тренинга. У својим текстовима Верхошански започиње веома оштру критику теорије Матвејева. Верхошански (Верхошанский, 2005) дорађује првобитну поставку нове теорије спортског тренинга која добија свој пуни назив блок систем спортског тренинга.

Шта, заправо, Верхошански замера Матвејеву? Критика отпочиње казивањем да је традиционални приступ „Изгубио битку” са временом и да није утемељен на новијим ठиолошким знањима, која према речима критичара, играју одлучујућу улогу у разумевању процеса управљања спортском формом. Ту чињеницу потврђују многобројни специјалисти широм света из области спортског тренинга. Даље, Верхошански не негира важност философије науке, методологије или педагогије, али примат даје објективним знањима која се сти- чу експериментално и практично. Ту се у првом реду мисли на знања из области као што су физиологија, биохемија или биомеханика. На основу таквих знања он развија свој теоријски систем са појмовном структуром и закономерним односима. Верхошански је критиковао традиционални приступ теорије спортског тренинга у више наврата, али, чини се, да ју је на најсвеобухватнији начин представио кроз седам тачака у свом раду На путу ка научној теорији и методологији спортског тренинга, а у којима се наводи следеће (Верхошанский, 1998b):

- најозбиљнији порок КПСТ (концепцији периодизације спортског тренинга) који је лишава, како теоријског, тако и практичног значаја, је запостављање биолошких знања и научних достигнућа у области спорта;

- последица методолошке и научне неприкладности КПСТ, је очевидна појмовна збрка „закономерности“, „принципи“, „полазна полазишта“, „принципијелно полазиште“, „закономерне карактеристике/црте“, а та збрка изазвана је чудним и бесперспективним покушајем тражења закономерности у искуству изградње спортског тренинга;

- спекулативно-логичка основа КПСТ произашла је из такозваних фаза формирања спортске форме;

- „општи педагошки приступ“ не темељи се на: озбиљној природној научној основи, објективним, квантитативним критеријумима свога предмета и строгим научним методом, зато не може постојати теоријско-методолошка база теорије спортског тренинга;

- озбиљна критика од стране специјалиста-практичара, односи се на саму суштину КПСТ - формалном, механичком дробљењу процеса тренинга на субјективну поделу његових делова (циклусе, етапе, периоде), а у чему је била главна идеја и смисао КПСТ;

- најнеразвијенији део КПСТ је технологија изградње процеса тренинга који се заснива на принципу „може тако, а може и овако“;

- један од најсуштинскијих недостатака КПСТ је што она омогућава само два метода/начина (обим и интензитет оптерећења) регулисања утицаја тренирања на спортисту. 
Критику коју је започео Верхошански, проширио је Исурин (Иссурин, 2010, стр. 101-106), који наводи следеће противречности ТТСТ:

- традиционално планирање добро је за спортисте ниске и средње квалификације. Међутим, оно недовољно добро функционише код спортиста високе класе;

- паралелна примена различитих оптерећења доприноси адекватном обезбеђивању енергије,

- због хетерохроности опоравка физиолошких система спортисти се не опорављају довољно;

- вежбе које су коришћене при реализацији различитих метода тренинга, често имају негативан узајамни утицај због дефицита енергије, техничке сложености и/или нервно-мишићног замора;

- примена великих оптерећења на тренингу захтева висок ниво психичке концентрациje, коју је немогуће усмерити на више циљева истовремено;

- специфична прогресија спортиста високог нивоа захтева примену утицаја тренинга великог обима који не може бити организован на тренингу због великог броја циљева.

Са друге стране, Матвејев (Матвеев, 1998а) подсећа Верхошанског да занемарује новија истраживања о теорији спортског тренинга, као и целовит приступ у изучавању спортског тренинга. Заправо та нова истраживања практично су проверена широм света од стране многих научних и спортских радника. Дакле, остаје нејасно, подсећа Матвејев, због чега Верхошански није уважио мишљења и других аутора и специјалиста широм света који су дали велики допринос динамици развоја традиционалне теорије спортског тренинга. Међутим, стиче се утисак да је кључани проблем у целокупној расправи, према Матвејеву, разумевање целовитости динамике такмичења и процеса тренинга и човека као учесника у њему. Матвејев је присталица холистичког приступа са стваралачким процесом и исходом и сматра да је недопустиво парцијално разматрати само један од многобројних проблема сада већ опште теорије спорта. Тај став се можда најбоље видети у његовом исказу: „Поћи у жестоку стандардизацију - значи ући у непомирљива противречја живе варијативности процеса тренинга“.
Поред Матвејева и други аутори су имали примедбе на блок систем спортског тренинга, међу којима се може издвојити Платонов (Платонов, 1998) који је на следећи начин изложио своје неслагање са теоријом Верхошанског:

- критика се своди на анализу само једног из многобројних делова система спортског тренинга - концепције периодизације коју је Матвејев објавио 1964. и 1977. године. На тој основи прави се увод о кризи не само домаће, већ и источноевропске теорије спортског тренинга;

- Верхошански замера Матвејеву да игнорише биолошка знања, а добро је познато Матвејево полазиште у којем се преплићу спортско-педагошка и биолошка знања. О томе сведочи литература коју је Матвејев цитирао - више од половине цитата су из области физиологије, биохемије и спортске медицине;

- библиографски показатељи о најважнијим текстовима су изостављени;

- Верхошански, критикујући Матвејева, позива се на то да се теорија Матвејева не разуме на Западу. Та констатација доведена је у питање, јер искуство у дијалогу са специјалистима из Јапана, Кине, Америке и Канаде сведочи обрнуто - теорија периодизације спортске припреме, као и различите варијанте њене практичне реализације, развијене су од стране стручњака СССР-а и НДР-а током 70-80-тих година, представља један из малобројних области знања у којем специјалисти из целога света дају безусловни приоритет источноевропској научној школи. Свидело се то некоме или не, са уважавањем се односе ка том доприносу, а познато је да је Матвејев највише допринео развоју поменуте источноевропске школе;

- Платонов сматра, да се теорија Верхошанског и не разликује суштински од теорије Матвејева по питањима принципа и додаје да се разлика може видети само у томе што Верхошански уводи одређене нове, до сада ненавикнуте термине, како за специјалисте са руског говорног подручја (рус. отечественных), тако и за остале иностране специјалисте - то не доноси ништа осим забуне; 
- проблеми о којима се расправља не могу се свести само на један проблем који постојано наглашава Верхошански;

- треба додати на овом месту да се Платонов, такође жестоко супротставио и ставовима који су изречени у раду Верхошанског, под називом Хоризонти научене теорије и методологије спортског тренинга (рус. Горизонты научной теории и методологии спортивной тренировки).

Платонов (Платонов, 2008, стр. 17-20) се оштро супротставио теорији Верхошанског и у новијим радовима:

- многи елементи критике су „бездоказни“, амбициозни и базирају се на тенденциозном и понекад грубом представљању основних полазишта теорије периодизације. Све то има за циљ да се оформи сопствена, алтернативна теорија програмирања и организације процеса тренинга;

- Верхошански излаже емоционалну критику, а не научну и практичну;

- ако се проблему приступи објективно, веома је тешко увидети шта је то ново што је Верхошански донео систему знања, која се односе на изградњу процеса припреме врхунских спортиста током године и макроциклуса. Није јасно на шта се своди његова претензија на откриће уникатног, раније непознатог феномена;

- принцип који је предложен, а тиче се изборноусмерених оптерећења (оптерећења која развијају само једну способност) и који у себи садржи велики интензитет-опоравак-одложни адаптациони ефекат био је детаљно размотрен, од стране бројних аутора, попут Консилмана, Озолина, Хареа, Матвејева и других, много пре него што је Верхошански о томе писао;

- једноусмерена концентрација оптерећења са великим обимом рада, која је карактеристична за савремени спорт, носи са собом и дру- ге опасности: 1) могућност функционалне потрошености (преадаптација), 2) снижење структурне и функционалне резерве других система (деадаптација), који се не укључују у потребној мери приликом вршења рада.

Постојећим критикама, на рачун теорије блок периодизације, придружио се и Кили (Kiely, 2010, стр. 803) подсећајући да преурањено и без подршке Исурин говори о „новим хоризонтима“ периодизације тренинга. Два су основна разлога за то: а) незванична је (енг. anecdotal) - садржи одабране примере/случајеве спортиста и тренера који су достигли високе нивое успеха користећи блок-тренинг дизајн; 2) „два савремена научна концепта" која се односе на кумулативни и остатни (енг. residual) ефекат тренинга, заправо не представљају ништа ново у тренингу. Заиста, Матвејев је најпознатији аутор традиционалног модела периодизације и он је такође узео у обзир, кумулативни ефекат тренинга и концепте који кореспондирају са остатним ефектом тренинга, у својој утицајној књизи Основи спортског тренинга. На крају Кили (Kiely, 2010, стр. 804) закључује да је прикладнији опис блок периодизације „нова варијанта“ него „нови хоризонт“ у планирању спортског тренинга.

Након критике коју је изнео Кили, уследио је одговор од стране Исурина. С обзиром да је у овом раду већ изложена Исуринова критика на рачун традиционалне теорије спортског тренинга, одговор Килију биће изостављен.

Дискусија се у новије време одвија на један, може се рећи, недовољно научно оправдан начин прегласавајућег карактера. Наиме у студији Гарсије Палареса и сар. (García-Pallarés, García-Fernández, Sánchez-Medina, и Izquierdo, 2010) пореде се утицаји два модела тренинга (традиционална периодизација са блок периодизацијом) на промену такмичарских способности код врхунских кајакаша. „Дизајн студије“ приказан је на Слици 1 и на њему се сажето може видети план тренинга, главни циљеви тренинга и календар тестирања за оба циклуса. 
Петровић А., Дијалог о теоријама спортског тренинга..., ФИЗИЧКА КУЛТУРА 2017; 71 (2): 172-181

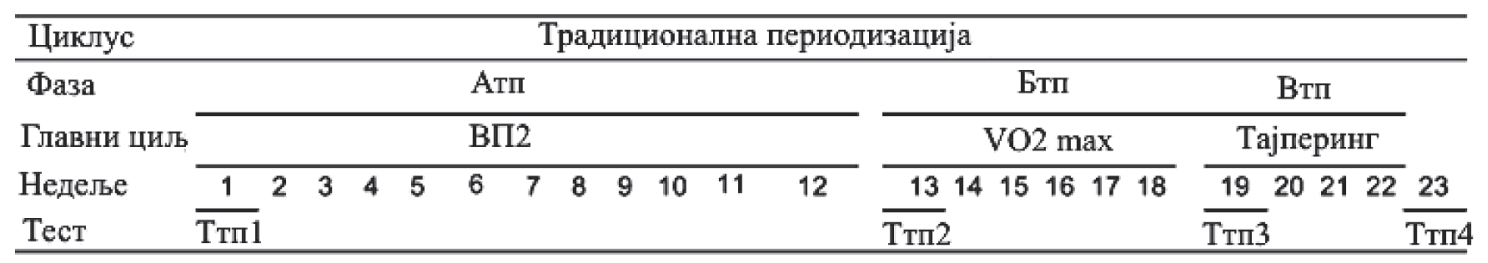

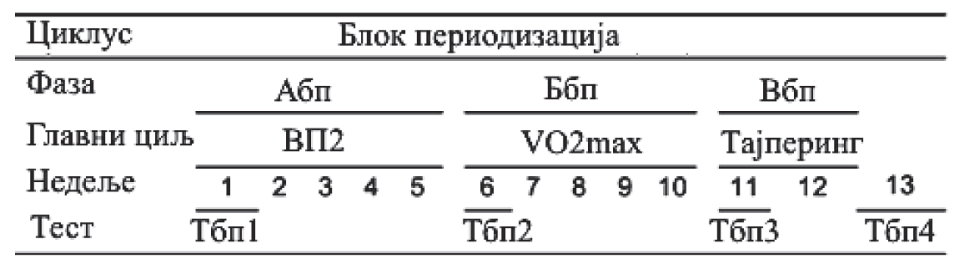

Слика 1. Дизајн студије Резиме плана тренинга, главних циљева и календара тестирања за оба циклуса. Прилагођено из: Гарсија-Паларес и сар. (García-Pallarés et al., 2010).

На основу таквог „дизајна студије“ изводи се закључак да је блок периодизација бољи начин планирања него традиционална периодизација и да више побољшава способности које су важне за кајакаше (García-Pallarés u cap., 2010). Међутим, ако са мало боље погледа „дизајн студије“ који је предложен, може се закључити да ови аутори праве разлику између блок периодизације и традиционалне периодизације, само по обиму оптерећења, а заборавља се да је модел односа обима и интензитета у ТТСТ и ТБПСТ аналоган - безмало исти. Такође, излаже се критика на рачун традиционалне периодизације, а да у литератури нема ни једног цитата који се тиче традиционалне периодизације спортског тренинга. Такав дијалог, једноставно нема методолошку оправданост јер не показује зрелост за највиши степен расправе о теорији спортског тренинга. Гарсија Паларис и cap. (García-Pallarés u cap., 2010) не разматрају детаљно класичне концепције традиционалне и блок периодизације, већ их слободно тумаче на спекулативан начин.

Сличан принцип се заступа и у другим истраживањима (Carazo-Vargas, González-Ravé, Newton, и Moncada-Jiménez, 2015; Rønnestad, Ellefsen, и cap., 2014; Rønnestad, Hansen, и Ellefsen, 2014) у којима се такође критикује традиционални модел периодизације спортског тренинга на један потпуно слободан и ванконтекстуалан начин, а у неким ситуацијама и на химеран начин. Поменути аутори, не наводећи ни један цитат аутора који су осмислили традиционалан модел, улазе у критику парцијалних елемената и своде традиционалну теорију на оно што она није.

Досад изложен и постављен проблем истраживања има пре свега научни значај, чији се смисао појављује у дијалогу. Али не било каквом дијалогу, већ дијалогу који ће имати јасне поставке и који ће имати свој почетак и крај. Научним дијалогом са почетком и крајем треба се дотаћи и ширег смисла постојања и разумевања човека. Иако се то обично не односи на научну нужност, што ће рећи да је могуће истраживати и на друге начине не узимајући у обзир шири контекст разумевања одређене проблематике - холистичко насупрот партикуларистичког схватања. Поред тога, разумевање човека кроз науку треба ићи у два смера: по ширини и по дубини. У супротном, ठез таквог сагледавања, лако се може оповршинити човек кога наука покушава да сагледа. Дакле, треба преиспитати на који начин се поставља проблем читаве теорије спортског тренинга и на који начин се закључивало у теорији спортског тренинга. Другим речима, може ли смисао и циљ теорије спортског тренинга бити ван смисла човека?

Овде треба додати да дијалог који се водио у оквиру теорије спортског тренинга има „чисто научни карактер“ који са собом носи једну мањкавост. Наиме, ако погледамо како су конституисане ове две теорије/концепције, и како се води дијалог, лако се може увидети да дијалог почива на чињеничном знању. Међутим, такво чињенично знање у теорији спортског тренинга намеће једно важно питање: на основу ког мерила/критеријума чињенице, приписане једној теорији, имају вреднији садржај него чињенице приписане дру- 
гој теорији? Аутори су се често позивали на своја, али и друга истраживања која чињенички доказују основне поставке једне или друге теорије. У првим расправама, дијалог засниван на таквим тенденцијама чинио се оправданим, међутим, након више изнесених критика са једне, али и са друге стране, прилике које су се појавиле у оквиру ове научне заједнице почеле су више да личе на „прегласавање“ него ли на ваљан научни дијалог у оквиру теорије спортског тренинга. Једноставно речено, консензус међу водећим теоретичарима није остварен по питању најважнијих проблема теорије спортског тренинга.

Из наведеног произилази и могућност решавања проблема који се односе и на спортску праксу, односно решавање практичних проблема, проблема „нижега реда”, али не мање важних. Заправо ти проблеми су проблеми одабира и приступа једног из предложених система и његове примене у практичном раду.

\section{КРИТЕРИЈУМИ ЗА ВОБЕЊЕ ДИЈАЛОГА О ТЕОРИЈАМА СПОРТСКОГ ТРЕНИНГА}

Научни дијалог у функцији оцењивања и упоређивања теорија отвара читав низ проблема у вези са: философијом и логиком науке, методологијом, затим самим феноменом који се испитује у некој научној области, али и решавањем практичних и других проблема. Пошто наука почива на критеријумима, оправдано је поставити питање: на основу којих критеријума се оцењују и упоређују научне теорије које решавају проблеме исте природе стварности у некој области истраживања, као и шта се подразумева под изразом критеријум?

Критеријум, критерији (грч. kritērion, према krínein), je: 1. основа према којој се нешто оцењуje, класификује односно разликује од нечег другог, мерило. 2. сп. елиминационо такмичење (Клајн и Шипка, 2008, стр. 681)

У новије време издвојиле су се три групе критеријума за оцењивање и упоређивање теорија спортског тренинга ${ }^{1}$ :

1 Детаљније о критеријумима у докторској дисертацији: Петровић, А. Теорије спортског тренинга: могућности оцењивања и упоређивања. Одбрана дисертације у припреми.
1) природа и порекло знања у теоријама спортског тренинга - крииееријуми засновани на ейисиеммолошким верованима;

2) начина истраживања у врхунском спорту, где је посебна пажња усмерена на разумевању примене научне методологије у наукама о спортском тренингу - крииетериуми засновани на метиоgолошким веровағима и

3) упоређивања научних теорија, односно стицање разлога оправданости једне теорије у систему неке научне дисциплине - критереијуми засновани на мулииияисиийлинарном йристиуйу оцењивања и упоређивања научних теорија, који са собом носе на пример, логичност, вероватноћу, смелост и/или једноставност теорије.

Треба указати да је досадашња расправа у теорији спортског тренинга била заснована на критеријумима, пре свега, уже стручне оријентације. Ти критеријуми и њихова исходишна знања се у многоме одликују практичним знањима. Наиме, образлагање неке од теорије спортског тренинга, од стране различитих аутора, било је усмерено више на разумевање праксе тренирања као једног од главних критеријума теоријске оправданости. Наравно, да је за спорт и спортски тренинг, посматрано као феномен, од значаја практично исходиште неке од теорија. Међутим, да ли је оправдано једну теорију процењивати само на основу практичних исходишта? По свему судећи, не! Зашто? Такав приступ говорења „за“ и „против“ једне теорије на основу само једног критеријума (у овом случају мисли се на праксу као исходиште) у многоме може упућивати на партикуларистичко схватање проблема. Пракса је само један сегмент, део, зрнце у разумевању једне проблематике која тежи или јесте научна.

Овде се заступа теза да се дијалог у оквиру теорије спортског тренинга треба проширити са претежно практичних критеријума, на претежно научне критеријуме у оквиру којих се могу оцењивати и упоређивати теорије (хипотезе) спортског тренинга. То не значи gа йракса није критиеријум науке, али тиакође не значи gа је ирракса јеgини критеријум науке каgа се іовори о иееорији

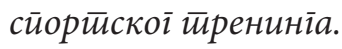




\section{ЗАКЉУЧАК}

Усавршавање знања у науци дуг је и мукотрпан посао. Дијалог је један од основних начина/ метода усавршавања науке. При одабиру решавања проблема треба разликовати проблеме који су вредни и који су мање вредни дијалога. Вредни проблеми се одликују смелошћу, да се дијалогом унапреди знање, тако што се постављају на „опаснији“ начин. Постављање проблема у коме нема неизвесности, заправо је успоравање сазнања, усавршавања, напредовања, а самим тим и научне дисциплине.

У теорији спортског тренинга започет је дијалог између присталица две метатеорије: традиционалне теорије спортског тренинга и теорије блок периодизације спортског тренинга. Основни мотив започетог дијалога је побијање, односно одбацивање традиционалне теорије спортског тренинга. Поменути дијалог не треба прекидати већ га треба изнова понављати, имајући у виду „нова“ и „стара“ знања, али не само да би се одбацила једна од теорија, већ да би се дошло до објективизованијег знања. Понекад може бити вредније оно што је заједничко теоријама, него оно што их раздваја. Дијалог представља нову могућност присталицама обе концепције спортског тренинга за будуће усавршавање научне мисли о спортском тренингу.

За плодан дијалог треба додати критеријуме по којима се он води, односно по којима се оцењују и упоређују теорије спортског тренинга. Један или мањи број критеријума, на којима инсистирају присталице ТБПСТ обеснажује дијалог. У теорији спортског тренинга као основни критеријум наметнута је пракса тренинга. Наравно да је пракса један од важних критеријума, али не треба забо-

\section{ЛИТЕРАТУРА}

1. Carazo-Vargas, P., González-Ravé, J. M., Newton, R. U., и Moncada-Jiménez, J. (2015). PeriodizatioModel for Costa Rican Taekwondo Athletes. Strength \& Conditioning Journal, 37(3), 74-83.2.

2. García-Pallarés, J., García-Fernández, M., SánchezMedina, L., и Izquierdo, M. (2010). Performance changes in world-class kayakers following two равити и остале критеријуме попут: критеријума који се тичу еиистемолошких и метоооолошких веровања, затим логичности, смелости, вероватноће, једноставности теорије и друге - мулиииguсиийлинарни приступ оцењивања и упоређивања теорија спортског тренинга. У том погледу Верхошанском и његовим следбеницима треба захвалити што су смело и „опасно“ ушли у дијалог са присталицама традиционалне теорије спортског тренинга и тиме унапредили научно знање о спортском тренингу, али треба жалити што је њихов „простор сазнања“ сведен само на „тврду суштину“, односно на емпиријска знања. Тиме се дала предност партикуларистичком закључивању о основним поставкама теорије спортског тренинга, а занемарило холистичко закључивање на шта подсећају присталице ТТСТ.

Стално богаћење дијалогом условиће толеранцију према другачијем и другоме, то не значи да науку треба релативизовати кроз став „све је дозвољено“, већ значи покушај објективизованијег усавршавања појединца, научне заједнице и знања у некој науци. Не треба сумњати да је дијалог поуздан пут/начин/метод сазревања и усавршавања знања у науци.

На страницама часописа Физичка кулі̄ура, Јевтић 1999 године, брзо након бурне расправе између присталица ТТСТ и ТБПСТ, указује на основне проблеме који се јављају у теорији спортског тренинга, чиме се и у српској периодици желело да се поспеши дух научног дијалога.

\section{НАПОМЕНА}

Изводи и допуна из необјављене докторске дисертације (одбрана у припреми): Петровић, А. Теорије спортског тренинга: могућности оцењивања и упоређивања. Докторска дисертација, Cpбија, Факултет спорта и физичког васпитања.

different training periodization models. European journal of applied physiology, 110(1), 99-107.

3. Issurin, V. (2010). New horizons for the methodology and physiology of training periodization. Sports medicine, 40(3), 189-206.

4. Kiely, J. (2010). New horizons for the methodology and physiology of training Periodization: Block 
Periodization: NeHorizon or a False Dawn?; The Author's Reply by Issurin, V. Sports medicine, 40(9), 803-808.

5. Koprivica, V. (2012). Block periodization-a breakthrough or a misconception. Sport Logica, 8(2), 93-99.

6. Poper, K. R. (1973). Logika naučnog otkrića (S. Novaković, превео). Beograd: Nolit.

7. Rønnestad, B. R., Ellefsen, S., Nygaard, H., Zacharoff, E. E., Vikmoen, O., Hansen, J., (2014). Effects of 12 weeks of block periodization on performance and performance indices in well-trained cyclists. Scandinavian journal of medicine \& science in sports, 24(2), 327-335.

8. Rønnestad, B. R., Hansen, J., и Ellefsen, S. (2014). Block periodization of high-intensity aerobic intervals provides superior training effects in trained cyclists. Scandinavian journal of medicine \& science in sports, 24(1), 34-42.

9. Верхошанский, Ю. (1998а). Горизонты научной теории и методологии спортивной тренировки. Теория и практика физической культуры (7), 41-54. Retrieved from http://lib.sportedu.ru/Press/ TPFK/1998N7/p41-54.htm.

10. Верхошанский, Ю. (1998b). На пути к научной теории и методологии спортивной тренировки. Теория и практика физической культуpal(2), 21-41. Retrieved from http://lib.sportedu. ru/Press/TPFK/1998N2/p21-26,39-42.htm

11. Верхошанский, Ю. (2005). Теория и методология спортивной подготовки: блоковая система тренировки спортсменов высокого класса. Теория и практика физической культурьы(4), 2-14. Retrieved from http://lib.sportedu.ru/Press/ TPFK/2005N4/p2-14.htm

12. Иссурин, В. (2010). Блоковая периодизащия спортивной тренировки: монография. Москва: Советский спорт.
13. Иссурин, В., и Шкляр, В. (2002). Концепция блоковой композиции в подготовке спортсменов высокого класса. Теория и практика физической культуры(5), 2-5.

14. Јеротић, В. (2013). Нема сазревања без ступања у дијалог са људима супротног мишљења. Куліичра, 140, 18-23.

15. Клајн, И., и Шипка, М. (2008). Велики речник ситраних речи и израза. Нови Сад: Прометеј.

16. Матвеев, Л. (1964). Проблема периодизации спортивной тренировки. Москва: Физкультура и спорт.

17. Матвеев, Л. (1977). Основы спортивной тренировки. Москва: Физкультура и спорт.

18. Матвеев, Л. (1998а). К дискуссии о теории спортивной тренировки. Теория и практика физической культуры (7), 55-61.

19. Матвеев, Л. (1998b). От теории спортивной тренировки-к общей теории спорта. Теория и практика физической культуры (5), 5-8Матвеев, Л. (2010). Общая тория спорта и ее прикладные аспекты. Москва: Советский спорт.

20. Озолин, Н. Г. (1951). О планировании спортивной тренировки. Теория и практика физической культуры (11), 848-855.

21. Озолин, Н. Г. (1959). Советская система спортивной тренировки. Теория и практика физической культуры(1), 7-11.

22. Платонов, В. (1998). О «Концепции периодизации спортивной тренировки» и развитии общей теории подготовки спортсменов. Теория $u$ практика физической культуры (8), 23-26.

23. Платонов, В. (2008). Теория периодизации подготовки спортсменов высокой квалификации в течение года: предпосылки, формирование, критика. Наука в олимпийском спорте(1), 3-23. 


\title{
DIALOG ÜBER THEORIEN DES SPORTTRAININGS IN FACHLICHER UND WISSENSCHAFTLICHER PERIODIK
}

\begin{abstract}
Zusammenfassung:
Der Zweck eines wissenschaftlichen Dialogs ist die Überwindung existierender Probleme, verantwortungsvolle Teilnahme, Kenntnis der Realität einer natürlichen Wirklichkeit im Gegenteil zu dem „Sich einschließen im Zimmer“ mit einer Theorie, der Erforschung einer Theorie, bis wir ihrem endgültigen Sinn auf den Grund kommen. Als eigentlicher wissenschaftlicher Dialog kann ein Dialog angesehen werden, dem ein ehrlich und "gefährlich“ gestelltes Problem vorangeht. Danach folgt ein verantwortungsvoller Versuch, das gestellte Problem zu lösen. Die Stellung der Kriterien, nach denen ein Dialog geführt wird, kann für die Kenntnis der Realität in einer wissenschaftlichen Disziplin wertvoll sein. Der Dialog über Theorien des Sporttrainings wurde vor langer Zeit begonnen; das Grundziel dieser Arbeit ist die Überwindung der Probleme, die sich auf „Theorien der Gegnerinnen“ beziehen - traditionelle Theorien des Sporttrainings gegenüber der Theorie der Blockperiodisierung von Sporttrainings. Das Problem des bisherigen Dialogs über Theorien für Sporttrainings war eine geringe Anzahl an Kriterien, auf Grund denen über „Theorien der Gegnerinnen“ diskutiert wurde. Der Dialog sollte widerholt werden, um zu einer toleranteren Einstellung gegenüber Anderem/Andersartigem zu gelangen oder um eine Meinung zu verstärken, die schon exixtierte.

Schlüsselwörter: THEORIE DES SPORTTRAININGS / DIALOG / TRADITIONELLE THEORIE / BLOCKPERIODISIERUNG / WISSENSCHAFTLICHE ZEITSCHRIFTEN
\end{abstract}

Примљен: 04. 11. 2017.

Прихваћен: 05. 12. 2017. 